\title{
Relationship Parenting Style and Self-Regulated Learning toward The Ability of Al-Quran Literation in Muslim Adolescents
}

\author{
Fairuz Nadiah $^{1}$ and Lydia Freyani Hawadi ${ }^{2}$ \\ \{fairuznadiahrozali@gmail.com ${ }^{1}$ \} \\ MiddleEast and Islamic Studies, School of Strategic and Global Studies, \\ Universitas Indonesia, Jakarta, Indonesia ${ }^{1}$ \\ Faculty of Psychology, Universitas Indonesia, Depok, Indonesia ${ }^{2}$
}

\begin{abstract}
Indonesia is the largest Muslim country in the world with a Muslim population of 201 million. Every Muslim is obliged to read and understand the Al-Quran as a way of life. However, the number of Indonesian Muslims who are still illiterate in the AlQuran is fairly high, reaching 65\% or around 135 million people. Various methods are used by the government to reduce the high number of illiteracy of the Al-Quran. One way is to include reading and writing lessons in the Al-Quran in the local content curriculum. However, the program was deemed not effective enough due to the lack of time provided in learning. Based on the results of interviews with several teachers of Islamic studies in schools, the low literacy of the Al-Quran on students is caused by internal factors namely, lack of motivation to learn and poor time management and external factors namely, lack of guidance from parents to learn the Al-Quran. In an effort to improve the ability of Al-Quran literacy in Muslim adolescents, researchers focus research on the external factors represented by parenting style and internal factors, represented by self reguated learning. This study aims to clarify the relationship between parenting style with the ability of newspaper literacy and the influence of self-regulated learning in improving the ability of Al-Quran literacy in Muslim adolescents. Data collection and processing in this study uses a quantitative method with the correlation test and multiple regression tests. The results in this study indicate that parenting does not correlate with the ability of the Al-Quran literacy in Muslim adolescents. Meanwhile, self-regulated learning has a correlation with the ability of the Al-Quran literacy in Muslim adolescents.
\end{abstract}


Keywords: Parenting-Style, Self-Regulated Learning, Al-Quran, Literacy, Islamic Psychology.

\section{INTRODUCTION}

Indonesia was the most Muslim population in the world. About $85 \%$ of Indonesian population or 201 million people of Indonesian were Muslim [1]. Although Indonesia holds the title as the country with the most of Muslims in the world, did not automatically make Indonesian Muslim population free from illiteracy of the Al-Quran. As the largest Muslim country in the world, the illiteracy rate of Al-Quran letters was still relatively high. Based on the results of a study by Al-Quran Science Institute (PTIIQ) in 2013, as many $65 \%$ of Muslims in Indonesia were illiterate in the Al-Quran, 35\% of them could read the Al-Quran but only 20\% could read the Al-Quran well [2]. The facts above was caused the level of illiteracy of the Al-Quran to Muslims in Indonesia very high, more than $50 \%$ or about 134 million Muslim population were illiterate in the Al- Quran and only 41 million Muslims could read the Al-Quran well.

Reviewing the Muslim situation in Malaysia as the second most populous Muslim population in Southeast Asia reaches 19 million out of a total of 32 million Malaysians, based on research conducted by [4] Malaysia had national program was formed to eradicate illiteracy of the Al-Quran since 2004, which was initiated directly by former Malaysian fifth minister, Tun Abdullah bin Haji Ahmad Badawi, named J- QAF. As national program, J-QAF considered capable and effective in increasing the literacy of Al-Quran in Malaysian Muslim communitiesin.

The Malaysian government believed by learning the Al-Quran, every Muslim would be able to improve the moral and religious values of Muslim communities and Malaysia proved it through research conducted by [5] that was ranked 1st of the most Islamic countries had implemented the most Islamic values in the world among the OIC member countries.

In the research conducted by [5], Indonesia was ranked 27th Islamic countries had implemented the most Islamic values in the world among the OIC member countries.

In a study conducted by [6] said that there was a positive relationship between the beliefs of a Muslim in the Al-Quran with the attitude they did. Thus, Thus, it can be concluded that the better a Muslim was in reading the Al-Quran, the better his religiosity woulld be. It caused he was able to live in accordance with the values contained in the Al-Quran. Researchers suspect, 
the low position of Indonesia in the implementation of Islamic values with other Islamic majority countries was one of the contributing factors, namely, the high level of illiteracy of the Al- Quran in Indonesia.

The population of adolescents in Indonesia was growing rapidly. Based on data from the Badan Pusat Statistik in 2010, 37\% of Indonesian population aged under 20 years, which means that the population of Indonesian youth was the most. Youth generation was also the next generation who would take over the role of the previous generation in various fields of development in Indonesia. When juxtaposed with demographic data of Indonesian population, which was predominantly Muslim, Indonesian Muslim adolescents had an important role to play in building Indonesia in accordance with Islamic values.

Based on observations and interviews conducted by researchers with several religious teachers in high schools, approximately $30 \%$ of students were unable to read the Al-Quran or did not knew the hijaiyah letters and the punctuation marks, $50 \%$ of them were able to read the Al-Quran but did not pay attention to recitation laws and $20 \%$ of students were able to read the AlQuran properly and correctly [7]. The low literacy skills of the Al-Quran in adolescent students were caused by external and internal factors. External factors include, lack of parental attention in guiding learning or reminding them to read the Al-Quran, the environment of adolescents living and socializing and economic status which results in limited learning facilities obtained. Meanwhile, internal factors faced by adolescents, those are, lack of interest in reading, difficulty in taking the time to learn Al-Quran literacy and the low motivation to learn Al-Quran literacy.

In an effort to improve the literacy skills of the Al-Quran in Muslim adolescents, researchers focused on external factor represented by parenting style and internal factor represented by self reguated learning. In a study by [8], the role of parents was one of the factors that could support the compatibility of learning outcomes with learning that children receive from school. Father and mother had an important role in the growth and development of a child [9]. Not only growth and development in children, parents were also an important source of religious influence [10]. The warmth of parenting caould be a bridge between parental religiosity and the religiosity of adolescents [11]. Therefore, parenting style also determines the conveyance of parents' religiosity to their children.

Besides that, Paris and Newman in [12] said that the more children grow up, the better their self-regulation to do their work. Self regulation in adolescents would help them in learning problems by creating the best atmosphere and learning methods those were in accordance with their personality. Self- regulated learning was needed by Muslim adolescents in 
addition to determine and manage independent learning as well as to increase self-awareness of the importance of learning Al-Quran literacy, not to get good grades at school but, to be able to read, understand the content of the AlQuran and use it as a way of life. This should be able to increase the motivation of learning literacy of the Al-Quran in Muslim adolescents which automatically increases the ability of Al-Quran literacy.

The problem of low literacy of the Al-Quran caused many emergent amoral problems that occur in adolescent students. On a small scale, increasing literacy of the Al-Quran can reduce moral problems in adolescents and on a large scale, increasing literacy of the Al-Quran could create a religious society had implemented the Islamic values. The combination of parenting style and self-regulated learning could be a solution to improve skill of the Al-Quran literacy optimally.

\section{LITERATURE REVIEW}

\subsection{Parenting Style}

Individual at the adolescent level were in transition from childhood to adulthood. At this time, individuals increasingly want to be free and look for identity, want to try new things and were easily carried by social currents because the thinking of adolescents becomes increasingly abstract, logical and idealistic. According to [13], those were two dimensions that make up a parenting style, there were, demandingness and responsiveness. The demands referred to in this theory are the behavior of parents who shape children into integrated individuals. Such behavior, among others, requests to be independent, supervise for discipline and reprimand when children were not obedient [14]. In other terms, Baumrind calls demandingness with behavioral control.

Then, responsiveness was the extent to which parents cultivate individuality and self-affirmation of children by supporting independence, agreeing to requests, providing warmth and logical reasons [15]. In other terms, Baumrind calls responsiveness with psychological control or psychological control. Furthermore, in this study used the word control and warmth. Baumrind uses control and warmth to identify parenting in three types, they were, authoritative, authoritarian and permissive. 
Although teaching Al-Quran literacy could be done anywhere, anytime and by anyone, but families, especially parents, were an important part of the ongoing education process. Parents must provide parenting, teaching and guidance to their children starting from infants, then grow into children, develop into adolescents and grow up until they were ready to live independently.

In line with the Islamic view, Allah says in Qs. At-Tahrim (66) verse 6 "O you who believe, protect yourself and your family from the fires of hell whose fuel is man and stone ..." and Hadith Bukhori No. History. 1296 "Every baby born in a state of pure nature. It was his parents who formed him into Jews, Christians or Majusians. "HR. Bukhari. It could be concluded that parents were responsible for each child's behavior and mindset.

In adolescence, an individual was still under the care of his parents.

When the Al-Quran literacy learning system in schools wass limited by minimal time, collaboration with parents (parenting) at home becomes one of the solutions that would have a positive influence on Al- Quran literacy for Muslim adolescents.

\subsection{Self-Regulated Learning}

Self-regulated learning was a learning process in which students direct themselves in transforming their mental abilities into academic skills. According to [16], self-regulated learning was an active and constructive process in which learners set goals for their learning then monitor, regulate, and control their cognitions, motivations, and behaviours.

The metacognitive dimension is students' knowledge of tactics in learning and their tendency to develop strategic planning when facing learning tasks. Cognitive processing includes automated processes related to attention, information storage, and implementation of tactics, for example focusing attention, regulation, and elaboration Meloy (2009) in [17]. Specifically, the types of strategies include the strategy of rehearsal, elaboration, organization, and the search for help from others and regulating the environmental utilization [18].

The dimensions of motivation are activities that are full of goals in starting, managing or increasing the willingness to start, prepare for the next task or complete certain activity tasks or according to purpose. An overview of student motivation in self- regulated learning consisting of self-efficacy, attribution, and task value Meloy (2009) in [19].

The strategy for regulating behavior is an individuals attempt to control their own visible behavior. Even so, individuals could observe, monitor, try to 
control and regulate it and as in general, these activities could be considered as self- regulatory for individuals. Behavioral regulation includes effort regulation, time and study environment and help- seeking.

According to Albert Bandura on social lerning theory, a person can learn by observing the actions of others. Means, parents who have a good understanding and ability about the literacy of the Al- Quran, so children tend to grow into a figure that was similar to observe the attitudes of their parents.

In the theory it is also mentioned that in shaping behavior, humans interact reciprocally on three things namely, behavior, environment and cognitive or behavior. All three interact and act as determinants and causes of one another [20]. Based on reciprocal theories of determination, it can be concluded that the literacy ability of the Al-Quran in Muslim adolescents was not only influenced by personal (cognitive) but also by environmental and behavioral factors. One of the environmental factors was parenting and behavioral factors were behaviors that support the improvement of the ability of the literacy of the Al- Quran such as taking notes and repeating lessons.

\subsection{Al-Quran Literacy}

[21] defines the term literacy as the ability to read and write, more profound literacy is not only a matter of written language skills but further oral communication of literacy was the ability to interpret and evaluate critically. Meanwhile, according to [22] literacy, namely, proficiency in language both in writing and verbally. In depth literacy could be interpreted as the ability to draw conclusions and think logically.

From this definition, it could be concluded that literacy is an activity more than just reading and writing. Furthermore, literacy could be interpreted as the ability to interpret, draw conclusions and think logically. However, in this study the meaning of literacy used in research is being able to read and recognize writing.

Al-Quran literacy is the ability to read and write letters in the Arabicspeaking Al-Quran. Furthermore, not only reading and writing, but can interpret and understand logically the contents of the Al-Quran verse. In this study, the meaning of Al-Quran literacy was limited only to the ability to read the Al- Quran.

There are four levels to understand the reading of the Al-Quran perfectly,

1. The basic level which consists of being able to recognize all letters of hijaiyah (Arabic letter), being able to distinguish punctuation marks and being able to pronounce hijaiyah letters correctly. 
2. The second level is, the intermediate level which consists of being able to read a combination of hijaiyah letters with different punctuation marks and being able to distinguish signs for stop and forbidden signs to stop.

3. The third level is the middle level which consists of being able to know the letters that must be read long and short and able to understand the laws of Tajweed.

4. The last level is the level of recitations which consists of being able to read the Al-Quran using songs or naghom [23].

\subsection{Adolescents Phase}

The term adolescene or teenager comes from the Latin word adolescere. In the Oxford dictionary, Adolescere means growing to maturity [24]. A broader definition of adolescence, that is, includes mental, emotional, social and physical maturity. According to Piaget in [25] adolescents were defined as individuals who have been able to integrate with society and are already on the same level as adults. At this time there will be many changes, especially physical and intellectual changes that were increasingly mature and have distinctive ways of thinking.

Diane E. Papalia and Gabriela Martorell in [26] stated that adolescence began to occur at the age of 11 years to 19 or 20 years, while the World Health Organization (WHO) determined the age of adolescents ranged from 10-19 years (WHO). According to [27] early adolescence is at theage of 10 or 12 years up to 18 to 22 years.

According Piaget's cognitive development theory, adolescents enter the formal operational phase, when individuals begin to be able to think more abstractly, idealistically, and logically than childhood [27]. Teens who reach the formal operational phase will be able to think abstractly; possibilities that will occur, resolve problems flexibly, and test hypotheses. Other advances experienced by adolescents were vocabulary and the ability to take a perspective on social perspective.

In adolescence, peers have the biggest influence on a teenager's social development. Peer friendship was increasingly tight, stable and supportive in adolescence, especially in adolescent girls. According to Bandura's social learning theory, adolescents learn about behavior and accept social norms from peers and reinforcement from peers towards behaviors that teens display. These social norms and teenagers' perceptions of norms provide guidelines for adolescents in making decisions, what behaviors they should or should not do.

Adolescence is a productive period both in learning and other physical activities. Therefore, maximizing their cognitiv with guidance from parents 
and good self-regulated learning was expected to be able to improve the literacy ability of the Al-Quran in Muslim adolescents.

\section{METHODS}

This study uses a quantitative approach

with non- experimental methods. Respondents in this study were 160 Muslim adolescent students (age between 15-18 years) from various schools background, including public and islamic school. Among them, 42,5\% were studying in high school (SMA), 6,9\% were studying in islamic high school, $23,1 \%$ were studying in vocational igh school.

The selection of respondents used convenience sampling tehniques defined by choosing respondents based on what researchers could reach. Respondents criteria are : 1) Muslim 2) Age 15-18 years

In this study, there were three instruments used they were;

1) Self-Regulated Learning Questionnaire Self-Regulated Learning questionnaire consist of 28 items total. 14 items that measured metacognitive, 8 items that measured motivation and 6 items that measured behavior. This overall self-regulated learning questionnaire has a validity coefficient of 0.930 and a reliability coefficient of 0.932 .

2) Self-Regulated Learning Questionnaire Parenting style questionnaire totaling 16 items. The questionnaire consisted of 7 items that measured parental control parenting and 9 items that measured warm parenting. The parenting questionnaire as a whole has a validity coefficient of 0.968 and a reliability coefficient of 0.918

3) Al-Quran Literation Questionnaire

Al-Quran Literation Questionnaire totaling 18 items. The questionnaire consisted of 5 items that measured at the basic level, 4 items that measured at the intermediate level, 6 items that measured at the advanced level and 3 items that measured at the reclining level. The Koran literacy questionnaire as a whole has a validity coefficient of 0.977 and a reliability coefficient of 0.961 .

\section{RESULT}

The following was the result of descriptive statistical analysis of research variables. 


\begin{tabular}{ccccc}
\hline Statistics & Contr ol & Warmth & $\begin{array}{c}\text { Self- Regulated } \\
\text { Learning }\end{array}$ & $\begin{array}{c}\text { Al-Quran } \\
\text { Literacy }\end{array}$ \\
\hline $\begin{array}{c}\text { Minimum } \\
\text { Seare }\end{array}$ & 15 & 14 & 4 & 71 \\
\hline $\begin{array}{c}\text { Maximum } \\
\text { Seare }\end{array}$ & 25 & 34 & 16 & 120 \\
\hline Range & 10 & 20 & 12 & 49 \\
\hline Mean & 20.35 & 25.9 & 11.16 & 95.72 \\
\hline Median & 20 & 26 & 12 & 95 \\
\hline Mede & 19 & 27 & 88 & 13 \\
\hline $\begin{array}{c}\text { Standard } \\
\text { Deviation }\end{array}$ & 2.51 & 3.12 & 2.94 & 10.89 \\
\hline
\end{tabular}

Fig 1. Descriptive Statistical Analysis of Variables

The results of the analyswas above show that, in the parenting style-control variable, respondents as a whole have a score range of 10, that was, from a minimum score of 15 to maximum score of 25 . The average control score was 20.35, the middle score (median) was 20, and the most appearing score (mode) was 19. Estimated average deviation of the respondent's score from the average score (standard deviation) of control is 2.51 .

Then, in the parenting style-warmth variable, respondents as a whole have a score range of 20 , that was, from a minimum score of 14 to maximum score of 34. The average warmth score is 25.9 the middle score was 26 , and the most appearing score was 27. Estimated average deviation of the respondent's score from the standard deviation of control is 3.12.

In the Al-Quran Literacy variable, respondents as a whole have a score range of 12, that was, from a minimum score of 4 to maximum score of 16 . The average control score was 11.16, the middle score was 12 , and the most appearing score was 88. Estimated average deviation of the respondent's score from the standard deviation of control was 2.94.

Meanwhile, on the self-regulated learning variable, respondents as a whole had a score range of 49 , that was, from a minimum score of 71 to maximum score of 120 . The average control score was 95.72, the middle score was 95, and the most appearing score was 13. Estimated average deviation of the respondent's score from the standard deviation of control was 10.89 . 
Then, the result of data statistical analysis of research variables.

\begin{tabular}{ccccc}
\hline Variable & Control & Warmth & SRL & $\begin{array}{c}\text { A-Quran } \\
\text { Literacy } \\
\text { Score }\end{array}$ \\
\hline Control & & $\begin{array}{c}0,557 \\
(p=0,000)\end{array}$ & $\begin{array}{c}0,458 \\
(p=0,000)\end{array}$ & $\begin{array}{c}-0,056 \\
(p=0,240)\end{array}$ \\
\hline Warmth & $\begin{array}{c}0,557 \\
(p=0,000)\end{array}$ & $\begin{array}{c}0,514 \\
(p=0,000)\end{array}$ & $\begin{array}{c}0,074 \\
(p=0,177)\end{array}$ \\
\hline SRL & $\begin{array}{c}0,458 \\
(p=0,000)\end{array}$ & $\begin{array}{c}0,514 \\
(p=0,000)\end{array}$ & & $\begin{array}{c}0,147 \\
(p=0,032)\end{array}$ \\
\hline Mean & $-0,056$ & 0,074 & 0,147 & $-0,056$ \\
\hline $\begin{array}{c}\text { Al-Quran } \\
\text { Literacy } \\
\text { Score }\end{array}$ & $\begin{array}{c}-0,056 \\
(p=0,240)\end{array}$ & 0,074 & 0,147 & \\
\hline significant for $p<0.05$ & & & & \\
\hline
\end{tabular}

Fig 2. Correlation Analysis Result

Based on the results of the correlation test, as shown in the table above, it was known that the parenting style control variable was not proven to be able to predict the improvement of the ability of Al- Quran literacy significantly because of sig. $=0.240(\mathrm{p}>0.05)$. That was, the high level of literacy competence of Muslim adolescents was not influenced by the parenting style control of the parents.

Likewise, for the variables of parenting style warmth also have not been proven to predict a significant increase in Al-Quran literacy abilities because of sig. $=0.177(\mathrm{p}>0.05)$. That was, the high level of literacy competence of Muslim adolescents was not influenced by the parenting style warmth of the parents.

Meanwhile, self-regulated learning variable can be proven to predict the improvement of Al- Quran literacy ability significantly because of sig. $=0.032$ $(\mathrm{p}>0.05)$. 


\section{CONCLUSION}

Based on the results of data analysis in this study, it can be concluded that there was no correlation between parenting parents the control dimension and the literacy ability of the Al-Quran significantly. This means that the high results of Al- Quran literacy competencies in Muslim adolescents were not correlated by parenting style control.

There was no correlation between parenting parents in the warmth dimension and the literacy ability of the Al-Quran significantly. That was, the high and low results of Muslim adolescents literacy competencies were not correlated by parenting style warmth for parents.

There was a positive correlation between self- regulated learning and the literacy skills of the Al- Quran significantly. This means that the high level of Muslim adolescents literacy competency results were correlated by selfregulated learning in Muslim adolescent.

\section{DISCUSSION}

Based on the results of data analysis in this study, it showed that there was no correlation between parenting style both control and warmth dimension toward literacy skills in adolescence. Adolescents were in a period of transition from the age of children to early adulthood. At this time, adolescent independence was increasing (Santrock, 2007). Families in this case were parents play the role of a adolescent who takes a role in making decisions. In the context of this research, parents control and warmth were no longer a focus for adolescents to learn Al- Quran literacy. They chooses the things were more representative of his interests.

On the other hand, there will be increase interaction outside family environment between adolescent an peers in adolescence phase. Peers are considered to be able to give references to their identity. It is also one of the factors that does not correlate parenting style with the Al-Quran literacy skills because adolescents tend to see the environment of their peers and imitate the same thing both positive and negative.

In this study, the high and low Al-Quran literacy is also influenced by the environment outside the home, that is, the social environment or peers. Whereas, based on the results of data analysis in this study indicate that there is a positive relationship and influence between self-regulated learning and the Al- Quran literacy in adolescents. This is in accordance with what was said by 
Paris and Newman in Zimmerman (1990), that is, the more children grow up, the better their awareness to do the work from school is not just to complete obligations but to understand the purpose of the task.

The results of the data analysis test also show that among the three dimensions in self-regulated learning, only the behavioral dimensions that influence the Al-Quran literacy abilities of Muslim adolescents. The behavioral dimension consists of effort regulation, meaning that the teenager makes more effort so that the learning goals can be achieved. Time study environment, means to set the time and place by making a schedule to facilitate the learning process and finally, Help seeking means, trying to get help from peers, teachers and adults to In this study, the behavior of selfregulated learning influences the Al-Quran literacy by obtaining additional AlQuran literacy outside of school lessons or studying with peers.

Based on the results of data analysis, it was shown that the variables of parenting were not proven to correlate with the ability to recit the Al- Quran in Muslim adolescents. In the next study, the researchers suggested using a mediation model on variable parenting, self-regulated learning and Qur'anic literacy. Self-regulated learning is the link between parenting and Al-Quran literacy in order to be correlated. In addition, further research is also expected to be able to use other subjects, for example, in children. Parental care for children is more likely to have an effect.

Based on the results of this study, researchers also gave advice to parents. In adolescence, parents must compete to grab the attention of children from peers so that negative influences from outside the family environment can be reduced. The teenage phase becomes the end of parental intervention in the lives of teenagers before the teenager can live independently by applying certain principles and ideologies. Therefore, planting Islamic values logically can be done in the adolescent phase because of the thinking that has developed.

In the next study, researchers also hoped to use other research methods such as qualitative or mixed methods in order to get different perspectives in looking at the effects of parenting, self-regulated learning and parenting. The researcher realizes that this study has several limitations including the distribution of parenting variables in two dimensions namely, control and warmth so that the type of parenting, authoritative, authoritarian and permissive is less to be explored for its role in relation to Al- Quran literacy. Researchers hope that in the next study, parenting style with Al-Quran literacy can be seen from the point of view of parenting type so that the type of parenting that has the most influence on Al- Quran literacy can be found. In the adolescent phase has diminished so that in the results of this study, 
parenting style do not have a correlation with the Al- Quran Literacy. Therefore, further research is expected to use different subjects for parenting rather than adolescents able to achieve learning goals.

\section{ACKNOWLEDGEMENTS}

This research was supported by Dana Hibah Penelitian Tugas Akhir 2018, Universitas Indonesia.

\section{REFERENCES}

[1] Badan Pusat statistik., (2010). Penduduk Menurut Wilayah dan Agama yang Dianut. Retrieved 18 April 2018 (time : 20.33), from https://sp2010.bps.go.id/index.php/site/tabel?tid=3 21

[2] Republika.co.id., (2018). Buta Aksara Alquran Tinggi, Ini Penyebabnya Kata Kemenag. Retrieved 15 April 2018 (time : 13.11), from http:/www. Khazanah.republika.co.id/berita/dunia-islam/islam-aksarakemenagnusantara/18/01/18p2r28k396-buta-alquran-tingi-ini-penyebabnyakata

[4] Ismail, D. Khairuldin, W. Mohammad, M. (2014) Perkembangan dan Masalah Pembelajaran al-Quran dalam Program j-QAF di Malaysia. Islamiyyat. 36(2), $57-66$.

[5] Rehman, S. S. Askari, H. (2010). How Islamic are Islamic Countries?. Berkeley Electronic Press. 10 (2)

[6] Masri, A. J. Priester, P. E. (2007). The Development and Validation of a Qur'an-Based Instrument to Assess Islamic Religiosity: The Religiosity of Islam Scale. Journal of Muslim Mental Health. 2(2)

[7] Budiarti, Tia. A. ( 2018, 18 Mei )., Wawancara Pembelajaran Alquran di Sekolah dengan Guru Agama Islam. (Fairuz Nadiah, interviewer)

[8] Muhamad, N.A.F. Hamzah, M. I. Tamuri, Ab. Halim, J. N. Ghazali, N. M. Amat, R. A. Raus, N. M. Hassan, S. N. The Importance of Positive SelfConcept for Islamic Education Teachers as a Role Model. US-China Education Review. 3 (1), 29-35

[9] Gežová, K. C. (2015). Father's and Mother's Roles and Their Particularities in Raising Children. Acta Technologica Dubnicae, 5(1), 45-50. (DAOJ)

[10] Bao, W.L., Whitbeck, L.B., Hoyt, R.D., Conger, D.R. (1999). Perceived Parental Acceptance as a Moderator of Religious Transmission 
among Adolescent Boys and Girls. Journal of Marriage and Family. 61(2).pp. 362-374

[11] French, D. C., Eisenberg, N., Sallquist, J., Purwono, U., Lu, T., \& Christ, S. (2013). Journal of Family Psychology, 27 (3), 421-430. (APA)

[12] Zimmerman, Barry.J. (1990). Self-Regulated Learning and Academic Achievement: An Overview. Educational Psychologist, 25:1, 3-17, DOI: 10.1207/s15326985ep2501_2

[13] Baumrind, D. (1966). Effects of Authoritative Parental Control on Child Behavior. Child Development, 37(4), 887-907.

[14] Baumrind, D. (2005). Pattern of Parental Authority and Adolescents Autonomy. New Direction for Child and Adolecents Development, no. 18, Summer 2005. Wiley Periodical, Inc.

[15] Baumrind, D. (2005). Pattern of Parental Authority and Adolescents Autonomy. New Direction for Child and Adolecents Development, no. 18, Summer 2005. Wiley Periodical, Inc.

[16] Zimmerman, Barry.J. (1990). Self-Regulated Learning and Academic Achievement: An Overview. Educational Psychologist, 25:1, 3-17, DOI: $10.1207 / \mathrm{s} 15326985 \mathrm{ep} 2501 \_2$

[17] Susanty, Rizky., (2017). Hubungan Antara Performance Goal Orientation dan Self- Regulated Learning dengan Kepribadian sebagai Moderator pada Siswa di SMA yang Menerapkan Kurikulum 2013. Depok : Universitas Indonesia

[18] Harris,B.R. Lindner, R. W. Piña, A.A. Strategies to Promote SelfRegulated Learning in Online Environments. USA: IGI Global

[19] Susanty, Rizky., (2017). Hubungan Antara Performance Goal Orientation dan Self- Regulated Learning dengan Kepribadian sebagai Moderator pada Siswa di SMA yang Menerapkan Kurikulum 2013. Depok : Universitas Indonesia

[20] Bandura, Albert., (1977). Social Learning Theory. US : PrenticeHall.Inc

[21] Kern, R. (2000). Literacy and Language Teaching. http://teslej.org/ej19/r5.html. Oxford: Oxford University Press.

[22] Wallendorf, Melanie., (2001). Literally Literacy. Journal of Consumer Research, Vol. 27, No. 4 (March 2001), pp. 505-511. Oxford University Press. http://www.jstor.org/stable/10.1086/319625 Accessed: 13-05-2018 12:36 UTC

[23] Alfatiri, Marzuki ( 2018, 31 Mei )., Wawancara Penyusunan skala Literasi Alquran dengan Pakar Ilmu Alquran LBIQ. (Fairuz Nadiah, interviewer) 
[24] Oxford University Press. (2018). Parenting. Retrieved Mei 08, 2018, from English-Oxford Living Dictionaries: https://en.oxforddictionaries.com/definition/parenting

[25] Hurlock Elizabeth, B., (2015). Psikologi Perkembangan : Suatu Pendekatan Sepanjang Rentang Kehidupan. Jakarta : Erlangga

[26] Herawan, Kinta E., (2018). Pengaruh Gaya Pengasuhan Ibu dan Perilaku Proposial Remaja Terhadap Toleransi Beragama Remaja Muslim. Jakarta : Universitas Indonesia

[27] Santrock, J.W. Adolescence. United States: McGraw-Hill Education 